\title{
Macroseismology: the lessons learnt from the 1997/1998 Colfiorito seismic sequence
}

\author{
Romano Camassi, Raffaele Azzaro and Andrea Tertulliani \\ Istituto Nazionale di Geofisica e Vulcanologia, Sezione di Bologna, Italy
}

\begin{abstract}
The seismic sequence of the Umbria-Marche Apennines was a dramatic moment for the population involved. At the same time, it provided a unique occasion for the Italian scientific community and for the national civil protection to assess their respective abilities in understanding and managing the event. Furthermore, macroseismology (including historical seismology) has knowingly tackled important methodological problems, such as the procedures for assigning macroseismic intensity, the use of the macroseismic scale, the impossibility of distinguishing the effects of earthquakes following closely in both space and time, within such a complex sequence. Starting from an analysis of the problems faced after the 1997/98 Umbria-Marche earthquakes, as during the following seismic crises over the last 10 years, we propose some considerations on the lessons we have learnt from that seismic sequence.
\end{abstract}

Key words macroseismology - macroseismic scales - intensity - Colfiorito earthquake

\section{Introduction: Macroseismic practice, macroseismology and historical seismology.}

The study of earthquakes through the collection and evaluation of the macroseismic intensity with respect to the effects on people, objects, buildings and nature is commonly known as «macroseismology» (Musson and Cecic, 2002; Cecic and Musson, 2004). Macroseismology defines the scenarios around both recent and historical earthquakes by means of accurate observations of the effects on the territory, especially in the damaged zones. The information collected is then elaborated and interpreted in terms of the intensity, namely a classi-

Mailing address: Dr. Romano Camassi, Istituto Nazionale di Geofisica e Vulcanologia (INGV), Sezione di Bologna, Via Donato Creti 12, 40128 Bologna, Italy; e-mail: camassi@bo.ingv.it fication of the severity of the ground shaking on the basis of the effects observed over a limited area (Grünthal [ed], 1998). The branch of macroseismology that collects and evaluates information on the effects of past earthquakes through archive sources (such as seismological compilations, coeval reports, and gazettes/bulletins) uses methods that are typical of historical investigation, and is known as historical seismology.

Macroseismology and historical seismology have common objectives, procedures and interpretive tools. The only difference between these two branches of seismology lies in the fact that in historical seismology the information is obtained from documents that are very variable in nature, and for which the collection and interpretation involves the use of critical tools that are specific to quantitative historical studies.

The aim of macroseismology is to define the physical characteristics of an earthquake, as expressed by a collection of parameters, through the reconstruction of its impact on the natural and built environment. Macroseismology is not an alternative to instrumental seismology: it is instead deeply complementary. Instrumental 
seismology has seen important developments in only the past few decades, and sufficiently representative instrumental data are available only for a very limited time window. For this reason, until a few decades ago, macroseismic data were usually the only data available for earthquakes that occurred. Nevertheless, it is important to stress that macroseismology provides essential and original information also for recent events for which also reliable instrumental data are also available.

Thus the main tool of macroseismologists is the intensity scale, a classification system that «allows the compression of a verbose description of earthquake effects into a number» (Musson and Cecic, 2002). Macroseismic scales have been conventionally coded over a century of practice. The Mercalli-Cancani-Sieberg (MCS) scale (Sieberg, 1930) and the European Macroseismic (EMS-98) scale (Grünthal [ed], 1998) are at present those most used in Europe.

\section{Macroseismic survey of the $1997 / 98$ Umbria-Marche earthquakes}

Since 26 September 1997, a task-force of researchers has carried out macroseismic surveys to obtain a rapid evaluation of the maximum effects produced by the main earthquakes of the sequence (fig. 1), in order to define the areas of damage, and in support of the rescue operations of the Dipartimento Nazionale di Protezione Civile (DPC). The numerous researchers who were involved belonged to the Gruppo Nazionale per la Difesa dai Terremoti (GNDT), the Istituto Nazionale di Geofisica (ING), the Servizio Sismico Nazionale (SSN) and the Uprava Republike Slovenije za geofiziko (URSG).

Although they operated in different ways, the teams involved were well aware of the need for cooperation: they set up a coordinating unit and a centre for the exchange of information. Different teams, consisting of 2-4 people, operated simultaneously in the field, visiting inhabited centres and rural villages following a programme that was scheduled the day before by the coordinating unit. At the end of each day, the field teams discussed the results of their sur- veys and compiled an upgraded intensity map. Thus, while working against the clock and under difficult conditions, they carried out the essential task of providing the DPC and the scientific community with an enormous set of data in a very short time. It should also be noted that this was the first occasion on which the Internet was efficaciously used by Italian researchers as a fast communication and data-storage tool, to the huge acclaim of all of the parties concerned (Stucchi, 1997).

From its very start, the survey campaign proved extremely taxing and complex, on account of both the extensive area to be covered (the entire territories of the Umbria and Marche Regions) and the continuously ongoing seismic activity. Each further strong shock modified the situation so that the level and distribution of the damage was altered and the survey had to be partially repeated. A vast amount of photographic documentation was collected, together with local evidence from interviews with expert witnesses (e.g., firemen, municipal officers, surveyors). The results of the field surveys were integrated with those of the macroseismic questionnaire that was later routinely collected by ING through the postal service. The resulting data mainly contributed to the definition of the effects in the far-field.

The first evaluation of the effects was carried out according to the MCS scale. Once the initial emergency was over, a trial of the EMS scale, at that time the EMS-92 one (Grünthal [ed], 1993), was also performed. This was of great interest as a test of the new scale, the special requirements for which (information on the building typologies in each locality, survey of the damage distribution for each building typology) would have been hard to reconcile with a quick survey (Stucchi [ed], 1997).

Most of the assessments relating to the macroseismic effects of the 1997/98 sequence are based on the results of the surveys in the area (Camassi et al., 1997a; Gasparini et al., 1997; Molin et al., 1997; Monachesi et al., 1997; Stucchi [ed], 1997; Camassi et al., 1998, Tosi et al., 1999; Camassi, 2002) and the critical analysis of the daily field diaries and technical reports of the building safety assessments. 


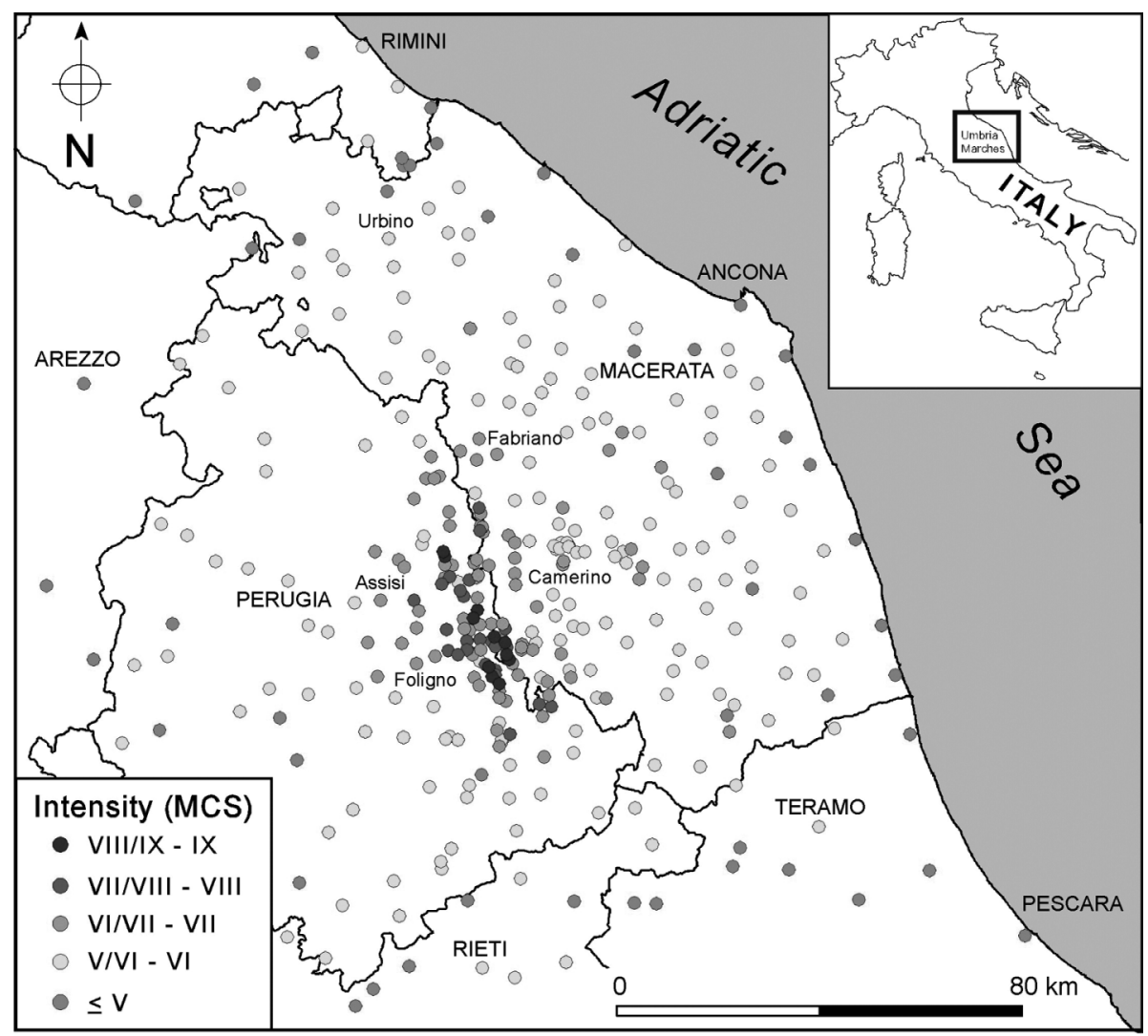

Fig. 1. Distribution of macroseismic intensities observed of the 26 Semptember 1997 earthquake and following days (Monachesi et al., 1997; update 7 October 1997)

\section{From Practice to Practice: The Umbria-Marche Lesson}

The 1997/98 seismic sequence was the most momentous crisis since the 1980 Irpinian earthquakes (6 shocks with $M>5.0$ ). In this sense, it provided an important occasion for the Italian scientific community to test its ability to investigate the effects of earthquakes, and at the same time to manage their relations with the national civil protection system in order to cope with such an important emergency. The long seismic period revealed a scientific community that was not ready for field surveys of damage over very large areas, and that lacked the support of adequate technical/financial resources and the a-priori organisation. Nevertheless, over a time-span of a few hours after the first strong event, the operators themselves built up the coordination and invested all of their energy in starting the macroseismic survey.

The experience of the 1997/98 UmbriaMarche earthquakes has highlighted a series of critical points that tested Italian macroseismic practice. From the problems that were faced on that occasion, as during the following seismological crises over the last 10 years, the main points that are brought together here concerned:

a) the collection and organisation of the data;

b) the types of data collected;

c) the georeferencing of the data;

d) the use of the macroseismic scales; 
e) the possibility of distinguishing the effects of single shocks within a sequence.

\subsection{Collection and organisation of the data}

Macroseismic surveys, questionnaire collection, and more recently, Internet polls have been used for gathering information on recent earthquake effects in Italy:

- For major events, a direct survey is certainly the most important method for data collection. Just before the Umbria-Marche experience, a joint effort between the operative groups of the different institutes involved in macroseismic surveys had begun for the Massa Martana earthquake in May 1997 (Camassi et al., 1997b). The Umbria-Marche sequence provided the occasion for the decisive push for strong collaboration between the different groups, and over only a few years, this led to the creation of a single organisation, which was also aided by the joining of the various research institutes into the Istituto Nazionale di Geofisica e Vulcanologia (INGV). This working group, called Quick Earthquake Survey Team (QUEST), had the duty to monitor the effects of all Italian earthquakes above the damage threshold, through the integration of the different experience and competence, and eventually with the aid of other personnel from different agencies. Since 2001, QUEST has undertaken the collection of macroseismic data during around 60 significant earthquakes. This has been achieved by direct surveys involving about 20 people, who alternate in their participation in the surveys, depending on the earthquake size, its epicentre location, and staff availability. The distribution of the INGV sections throughout the Italian territory makes it possible to intervene not only in cases of severe earthquakes, but also for moderate events. Each local group (Bologna, Catania, Milano, Napoli and Roma) has the responsibility as the «guardian» for that part of Italy that falls within its range of action. In the case of an event, the reaction time is very fast: when alerted by SMS from the INGV automatic location system of the national seismic network, the survey is organized in the following three-four hours. It us- es a standard protocol to gather homogeneous data: direct field observations in the damaged areas, telephone surveys in the far-field, collection of macroseismic data on a standard questionnaire form for the assessment of the MCS scale and the EMS-98 scale. In the case of a significant emergency, the field teams are coordinated by a central bureau that updates the intensity map in real time, maintains contact with the Civil Protection authorities, and disseminates (when possible) the collected data via the Internet (QUEST, 2008).

- Several types of postal questionnaires have been tested in Italy over the last few decades by different institutions. The experience developed by ING (now INGV) with the «Bollettino Macrosismico» is the most representative, and has been under constant development since the 1970's. Although it contains some disputable elements, it has the merit of collecting a huge amount of data by means of a dense network of correspondents throughout Italy (over 8000 municipalities, 3000 Carabinieri stations and around 1000 Forestal Corp stations). This kind of monitoring provides information for all of the events of $M>3.0$ (see Gasparini et al., 1992; De Rubeis et al, 2005). However, this methodology needs planning and is slow - the questionnaires are sent by post - so the data are actually available only a long time after the earthquake. Finally, they are published yearly in the form of a paper bulletin. In addition, there are other occasional experiments with questionnaires involving schools and students, for the reporting of their experiences of felt earthquakes, in the framework of educational activities (Postpischl et al., 1991; Cubellis and Marturano, 2002)

- On the basis of American experience (see Wald et al., 1999; Atkinson and Wald, 2007; and references therein), over the last few years, trials with Internet polls have been run with the INGV (http://terremoto.rm.ingv.it/). As well as some debatable choices of the way of formalising the questionnaire and interpreting the answers, this method for the collection of data in Italy still suffers from the major variability in the distribution of Internet access throughout the country. This is particularly lacking in central-southern areas, owing to which a significant number of the questionnaires are complet- 
ed only in the large urban areas. Nevertheless, in the future this method of information collection is certainly destined to be of greater importance.

It is important to stress that regardless of the accuracy and the agreement between the forms used, both the traditional macroseismic questionnaires and the Internet polls are difficult to complete. Indeed, they can sometimes be potentially misleading in terms of a reliable assessment of the effects of damage. As we will see on discussing specifically how these scales should be used, the assessments require the collection and interpretation of precise information by expert operators, whether either the MCS scale or the EMS-98 scale is used. The use of the aforementioned questionnaires, to be revised and standardised, may be useful in defining the characteristics and extension of the areas involved in the far-field, and of the limits of the damaged areas.

An anomaly that needs to be stressed is that, although these three means of data collection are conducted within the INGV, they operate in independent ways, producing different results that are sometimes contradictory. It is hoped that in the near future these activities will be thoroughly reconsidered, and that the information can be collected in a coherent, or at least compatible way, so that it will be possible to combine the data. The case of the earthquake of 26 September 1997, for example, is representative: much disagreement was evident in the assessments of some serious effects in the same areas (table I).

\subsection{The type of data collected}

The macroseismic scales require the effects of earthquakes to be documented in relation to a significant sample, with reference to a given locality (Ferrari and Guidoboni, 2000; Guidoboni and Ferrari, 2000). In this way, the assessment of the intensity is representative of that locality. This is required since the perception of an earthquake is subjective and also because the effects on buildings and the environment can vary greatly within the sample. Mercalli himself was very clear on this point: «In judging the intensi- ty of a shock by its effects, there is the need to take into account the full damage and destruction, rather than a few isolated occurrences, which can often be caused by the particular conditions of some buildings rather than the intensity of the shock» (Mercalli, 1897). The guidelines and background material of the EMS-98 scale are even more explicit: «This entails, first, that the settlement is large enough for a statistically significant sample to be obtained, without being unduly affected by small-scale local peculiarities, and secondly, that it is not so large that genuine local variations are neglected [...] Thus intensity should not be assigned to a single building or street; neither should a single intensity be assigned to a metropolis or a county. In general circumstances, the smallest place should be no smaller than a village, and the largest no larger than a moderately sized European town [...] Monumental buildings are usually unique, or only a few such buildings occur in one place. Therefore, it is impossible to use the data relating to them in a statistical way as the scale requires. Such data must therefore be handled with care, as complementary to other evidence (if available).» (Grünthal [ed], 1998).

For these aspects, in the recent practice of Italian macroseismology, different situations have arisen that have been particularly critical. The «Bollettino Macrosismico» of the INGV, for example, collects and analyses information relating to the territory of a whole municipality, and not to a single locality, a practice that is detailed in a generic way in the text of the bulletin itself and that is in obvious contradiction with some of the fundamental requisites suggested by the originators of the macroseismic scales. Suffice it to see how large and complex the territory of the Foligno Municipality is, of how many settlements it is made up (hundreds), and how large the variability of the effects was during the Umbria-Marche earthquakes of 1997/98 (fig. 2). Such use in the collection of the data contributes to the spreading of the intensity values over areas that are too large, obscuring the real significance of the variability of the effects between one village and another (see, for example, Tertulliani, 2000).

Similarly, the INGV Internet questionnaire «Did you feel an earthquake?» (http://terremo- 
Table I. Comparison between the table of intensities (only damaged localities) for the 26 September 1997 earthquake, according to Monachesi et al. (1997; update 2 October 1997, column 1) and «Bollettino Macrosismico» (column 2).

\begin{tabular}{|c|c|c|c|c|c|}
\hline \multirow{2}{*}{$\begin{array}{l}\text { Locality } \\
\text { Serravalle del Chienti }\end{array}$} & \multicolumn{2}{|c|}{$\mathrm{MCS}^{1} \mathrm{MCS}^{2}$} & \multirow{2}{*}{$\frac{\text { Locality }}{\text { Popola (Foligno) }}$} & \multicolumn{2}{|c|}{$\mathrm{MCS}^{1} \mathrm{MCS}^{2}$} \\
\hline & $6 / 7$ & $8 / 9$ & & $7 / 8$ & \\
\hline Collecurti (Serravalle del Chienti) & 9 & & Scopoli (Foligno) & $7 / 8$ & \\
\hline Cesi (Serravalle del Chienti) & $8 / 9$ & & Serrone (Foligno) & $7 / 8$ & \\
\hline Costa (Serravalle del Chienti) & $8 / 9$ & & Colfiorito (Foligno) & 7 & \\
\hline San Martino (Serravalle del Chienti) & $8 / 9$ & & Fondi (Foligno) & 7 & \\
\hline Acquapagana (Serravalle del Chienti) & 8 & & Forcatura (Foligno) & 7 & \\
\hline Dignano (Serravalle del Chienti) & 8 & & Rio (Foligno) & 7 & \\
\hline Attiloni (Serravalle del Chienti) & 7 & & Volperino (Foligno) & 7 & \\
\hline Taverne (Serravalle del Chienti) & 7 & & Frontone & - & $7 / 8$ \\
\hline Sellano & $6 / 7$ & 8 & Gagliole & - & $7 / 8$ \\
\hline Forfi (Sellano) [Landslide] & $8 / 9$ & & Nocera Umbra & $7 / 8$ & $7 / 8$ \\
\hline Biscina (Sellano) & 7 & & Isola (Nocera Umbra) & 9 & \\
\hline Molini di Cammoro (Sellano) & 7 & & Moline (Nocera Umbra) & $8 / 9$ & \\
\hline Villamacina (Sellano) & 7 & & Aggi (Nocera Umbra) & 8 & \\
\hline Foligno & 7 & $7 / 8$ & Sorifa (Nocera Umbra) & 8 & \\
\hline Annifo (Foligno) & $8 / 9$ & & Nocera Scalo (Nocera Umbra) & $7 / 8$ & \\
\hline Arvello (Foligno) & $8 / 9$ & & Stravignano-Bagni di Nocera (Nocera U.) & .) $7 / 8$ & \\
\hline Verchiano (Foligno) & $8 / 9$ & & Bagnara (Nocera Umbra) & 7 & \\
\hline Casenove (Foligno) & 8 & & Colle Aprico (Nocera Umbra) & 7 & \\
\hline C.le delle Macchie (Foligno) & 8 & & Colle Croce (Nocera Umbra) & 7 & \\
\hline Cupigliolo (Foligno) & 8 & & Grillo (Nocera Umbra) & 7 & \\
\hline Capodacqua (Foligno) & $7 / 8$ & & Molinaccio (Nocera Umbra) & 7 & \\
\hline Colle San lorenzo (Foligno) & $7 / 8$ & & Salmaregia (Nocera Umbra) & 7 & \\
\hline Fraia (Foligno) & $7 / 8$ & & Valtopina & 8 & $7 / 8$ \\
\hline Franca (Foligno) & $7 / 8$ & & Acquacanina & 6 & 7 \\
\hline Leggiana (Foligno) & $7 / 8$ & & Camerino & $6 / 7$ & 7 \\
\hline Ponte Santa Lucia (Foligno) & $7 / 8$ & & Seola Bassa (Camerino) & $6 / 7$ & \\
\hline
\end{tabular}


Table I. (continued).

\begin{tabular}{|c|c|c|c|c|c|}
\hline Locality & $\mathrm{MCS}^{1}$ & $\mathrm{MCS}^{2}$ & Locality & MCS & $\mathrm{MCS}^{2}$ \\
\hline Agnano (Camerino) & 6 & & Monte Subasio & - & 7 \\
\hline Letegge (Camerino) & 6 & & Muccia & 6 & 7 \\
\hline Mergnano San Pietro (Camerino) & 6 & & Massaprofoglio (Muccia) & $6 / 7$ & \\
\hline Mergnano San Savino (Camerino) & 6 & & Preci & $7 / 8$ & 7 \\
\hline Torrone (Camerino) & 6 & & Castelvecchio (Preci) & 7 & \\
\hline Trebbio (Camerino) & 6 & & Corone (Preci) & 7 & \\
\hline Valle Vegenana (Camerino) & 6 & & Roccanolfi (Preci) & 7 & \\
\hline Biocco (Camerino) & $5 / 6$ & & Sassoferrato & 6 & 7 \\
\hline Canepina (Camerino) & $5 / 6$ & & Spello & $6 / 7$ & 7 \\
\hline Cerreto di Camerino (Camerino) & $5 / 6$ & & Collepino (Spello) & $6 / 7$ & \\
\hline Camporotondo di Fiastrone & - & 7 & San Giovanni (Spello) & $6 / 7$ & \\
\hline Cessapalombo & - & 7 & Valfabbrica & $6 / 7$ & 7 \\
\hline Fabriano & $6 / 7$ & 7 & Visso & $6 / 7$ & 7 \\
\hline Belvedere (Fabriano) & $7 / 8$ & & Riofreddo (Visso) & $7 / 8$ & \\
\hline Campodonico (Fabriano) & 7 & & Aschio (Visso) & 7 & \\
\hline Coccore (Fabriano) & 7 & & Rasenna (Visso) & 7 & \\
\hline Cupo (Fabriano) & 7 & & Pioraco & 7 & $6 / 7$ \\
\hline Fiuminata & $6 / 7$ & 7 & Sefro & 7 & $6 / 7$ \\
\hline Poggio (Fiuminata) & 7 & & Sorti (Sefro) & 7 & \\
\hline Sorifa (Fiuminata) & 7 & & Assisi & $6 / 7$ & $6 / 7$ \\
\hline Fossato Di Vico & $6 / 7$ & 7 & Armenzano (Assisi) & 7 & \\
\hline Osteria del Gatto (Fossato di Vico) & $6 / 7$ & & Cerreto di Spoleto & 6 & 6 \\
\hline Gualdo Tadino & $6 / 7$ & 7 & Ponte (Cerreto di Spoleto) & 7 & \\
\hline Caprara (Gualdo Tadino) & $6 / 7$ & & Sigillo & $6 / 7$ & 6 \\
\hline Rigali (Gualdo Tadino) & $6 / 7$ & & Colbassano (Sigillo) & 7 & \\
\hline
\end{tabular}

to.rm.ingv.it/) collects information that specifically refers to single buildings, or even to single apartments; the mechanism of the interpretation assigns an intensity to every single question- naire, and then treats the collected information statistically, a procedure that clearly contrasts with the aforementioned rules.

Analogous examples are also found in his- 


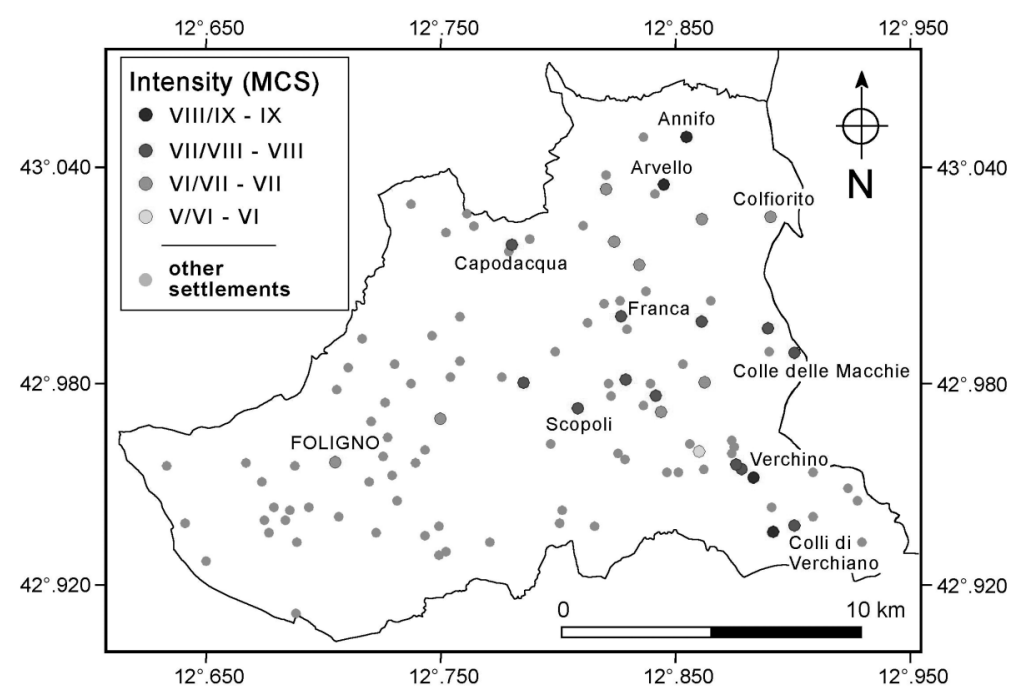

Fig. 2. Observed intensities (Monachesi et al., 1997; update 7 October 1997) in the territory of the Foligno (PG) municipality. In grey are plotted all settlements.

torical seismological studies. An eye-opening example of this type is that of the Bolognese earthquakes in 1929. An early study, reported by Camassi and Molin (1994), provided assessments of the effects relative to 109 localities; the later studies of Boschi et al. $(1997,2000)$ and Boschi and Guidoboni (2003) proposed the assessment of intensity for 640 and 691 places, respectively. As can be seen from the analysis of the data available for these studies, around 450 of such observations have been referred to single buildings, as can be explicitly seen from the technical surveys used in all these studies.

\subsection{The georeferencing of the data}

The geographical positioning of the locality with which the effects of an earthquake are associated - the macroseismic observations - is a simple routine operation that can sometimes present difficulties. The main causes of error concern the coincidence of names between places, the variation of names with the passage of time, and in the case of historical studies, the recognition of localities that no longer exist because they have disappeared or because they have been rebuilt in another place with a similar or a different name. All of these cases may result in errors in the drawing up of the macroseismic map, and moreover in the interpretation of the data. This was the case, for example, for some localities that were damaged during the Umbria-Marche sequence of 1997/98, which were differently located by Camassi et al. (1998) and, erroneously, by Boschi et al. (2000) (fig. 3).

To avoid these problems, a revision and unification of the geographical reference data was carried out, each locality being unequivocally identified with the same coordinates, which was used to set up of the DBMI04 Italian macroseismic database (Stucchi et al., 2007). In addition, a GIS-based utility for the management of macroseismic data, from the georeferencing with the above geographical directory to final plotting on the map, was also developed to provide a simple and quick tool to be used in the different phases of the macroseismic study (D'Amico and Azzaro, 2008). Finally, the current availability of good low-cost GPS systems, makes a faster and accurate georeferencing procedure in the field possible, though they must be then referred to the geographical directory. 


\subsection{The use of the macroseismic scales}

As indicated above, although in the literature there is no «code» for the use of the macroseismic scales, in practice certain ways of using them have been emerging over the last few years, in particular with the setting-up of the EMS-98 scale on a European level, both in its experimental version and in its definitive version (Grünthal [ed.], 1993, 1998). For the MCS scale itself, which is at present used only in Italy, in spite of its often rather casual use, it does contain some precise elements that are very informative indeed. In particular, Table 102 of the original text by Sieberg (1930), which is often disregarded by its users, offers some quantitative indications concerning the distribution of the different damage levels. These indications will be better stated in the versions of the MSK scale (Sponheuer and
Karnik, 1964) and the EM-98 scale, the guidelines for which are the only document in existence that addresses the use of a macroseismic scale.

However, it is important to stress that even the strict use of the MCS scale already requires the accurate acquisition of information, a quantitative analysis of the distribution of the various indicators considered (Molin, 1995, 2003), and moreover, a careful consideration of particular situations (high vulnerability, particular buildings, etc.).

\subsection{Evaluation of the effects of earthquake sequences}

As discussed above, the monitoring of damage due to the 1997/98 Umbria-Marche earthquakes was particularly problematic. First of

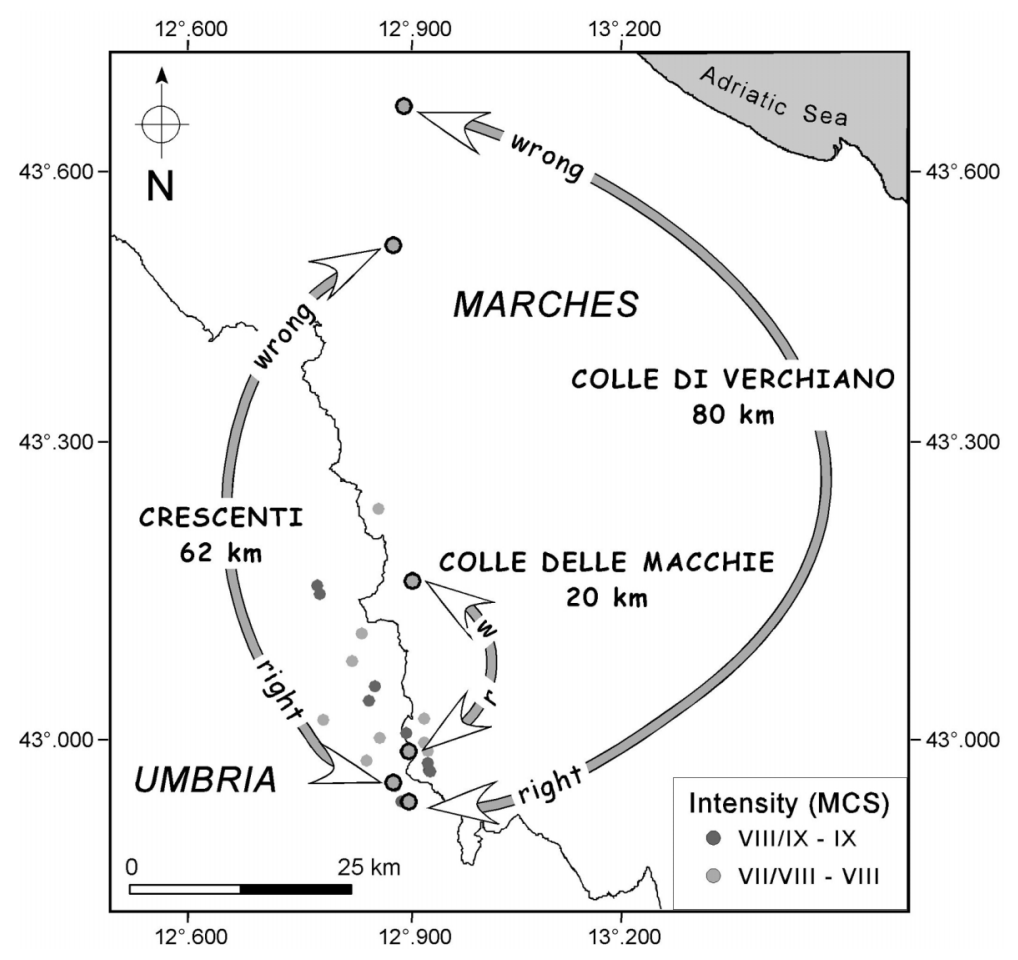

Fig. 3. Different locations of three damaged localities, according to Camassi et al. (1998) and Boschi et al. (2000). 
all, there was the general impossibility of distinguishing the effects of the individual events within the sequence. From 26 September to the end of October 1997, there were 27 earthquakes with magnitudes greater than 4.0 (six of which were greater than 5.0), while there were a few thousand events with lower magnitudes. These circumstances caused continuous variations in the damage levels even within the same areas, due to the cumulative effects of the shocks. Many towns were heavily hit many times, and it was rarely possible to quantify the increase in the damage in any way. Also, in the case of immediate and accurate field surveys soon after a shock, it was rather difficult to quantify the increase in building vulnerability due to these individual events (Azzaro and Stucchi, 2000). This means that the macroseismic effects arising from a seismic sequence should generally be considered to be cumulative rather than due to a single event; otherwise, the consequence will be the overestimation of the resulting intensity data (and hence also of the earthquake parameters derived from these data).

In conclusion, even when field surveys or historical sources report the effects of individual events, we can expect reliable data for the first event - although only if there is time enough to provide a clear damage scenario and cumulative effects for the entire sequence.

From this preliminary analysis, it follows that the intensity data relevant to destructive earthquake sequences can be biased by two factors: a vulnerability increase through the sequence, and the cumulative effects of the shocks. As a consequence, earthquake parameters derived from this sort of intensity data may also be biased, and in some cases, overestimated. Thus, it is critical to consider the vulnerability increase as an important bias for the intensity assessment within the same seismic sequence, because it does not produce «linear» variations in the final intensity.

\section{Conclusions}

The Italian seismological community has in general learnt a great deal from this 1997/98 Umbria-Marche seismic sequence while deal- ing with the questions and problems deriving from the huge amount of field data. Also, both macroseismology and historical seismology have faced important methodological problems over the last ten years. The main issue relates to the use of the macroseismic scales, and in particular for the procedures for assigning intensities. Due to the distribution and size of many inhabited centres (particularly in the case of a small settlement or isolated buildings) and the major differences in damage distribution over short distances (e.g. in volcanic areas), it has proven almost impossible to distinguish the effects of individual earthquakes within a seismic sequence.

In the practice of macroseismology today, however, we can consider that some lessons have been learnt, both in relation to recent earthquakes and to historical events. Since its formulation, the new EMS-98 scale has become more frequently used in Italy, although only after some initial perplexities (Molin, 1995; Tertulliani, 1995). This scale has been applied to a variety of cases, many of which have also included systematic comparisons with the MCS scale, which focuses on both the collection and interpretation of data collected in the field (Azzaro and Barbano, 1995; Azzaro et al., 2002, 2004, 2006), and the analysis and revision of historical sources, also in terms of seismic histories and damage scenarios for hazard purposes (Azzaro et al., 2000, 2007; Barbano and Rigano, 2001; Barbano et al., 2001, 2005). These $1997 / 98$ earthquakes represent an important moment in the aforementioned process, since it was the first experimental «laboratory» involving a large group of Italian operators working in macroseismology. Following the guidelines of the first version of the EMS-92 scale (Grünthal [ed], 1993), the participants made efforts to reduce the heterogeneity of the individual methodological approaches of the field surveys and intensity assessments (Stucchi [ed], 1997).

From a practical point of view, the QUEST working group has officially operated since 2004 , although it is actually nothing more than the formalization of the mobilization of researchers and technicians who participated on a voluntary basis ten years ago. In a more general framework of reorganisation of this sector 
within INGV, we expect that this group will become the hub of future activities in macroseismology, especially in setting up the process of harmonisation of survey procedures - direct observations in damaged areas versus questionnaires in the far-field, with only significant localities being checked - that will prove important for the production of reliable data.

\section{REFERENCES}

AtKInSON, G.M. and D.J. WALD (2007): «Did you feel it»? Intensity data: A surprisingly good measure of earthquake ground motion, Seism. Res. Lett., 78 (3), 362368.

AzZARo, R. and M.S. BARbano (1995): The Pollina (northern Sicily-Italy) earthquake of 26 June 1993: an application of the new European Macroseismic Scale 1992, Nat. Haz., 12, 289-301.

AzZARO, R. and M. STUCCHI (2000): The evaluation of the effects of earthquake sequences in the light of the EM98 intensity scale, in Papers and memoranda from the First Workshop of the ESC Working Group «Historical Seismology», edited by V. CASTELLI (Macerata, Italy, 15 September 1999), 48-53.

Azzaro, R., M.S. Barbano, B. Antichi and R. Rigano (2000): Macroseismic catalogue of Mt. Etna earthquakes from 1832 to 1998 , Acta Vulc., 12, (1-2), 3-36.

Azzaro, R., M.S. Barbano, R. Camassi, S. D'Amico, A. Mostaccio, G. Piangiamore and L. Scarfì (2004): The earthquake of 6 September 2002 and the seismic history of Palermo (northern Sicily, Italy): implications for the seismic hazard assessment of the city, J. Seism., 8 (4), 525-543.

Azzaro, R., S. D'Amico, A. Mostaccio and L. Scarfì (2002): Terremoti con effetti macrosismici in Sicilia orientale. Calabria meridionale nel periodo gennaio 1999 - dicembre 2001, Quaderni di Geofisica, 27, 59.

Azzaro, R., S. D’Amico, A. Mostaccio, L. Scarfì and T. TuvÈ (2006): Terremoti con effetti macrosismici in Sicilia orientale nel periodo gennaio 2002 - dicembre 2005, Quaderni di Geofisica, 41, 60.

Azzaro, R., F. Bernardini, R. CAmassi and V. Castelli (2007): The 1780 seismic sequence in NE Sicily (Italy): shifting an underestimated and mislocated earthquake to a seismically low rate zone, Nat. Haz., 42 (1), 149-167.

BARBANO, M.S. and R. RigANO (2001): Earthquake sources and seismic hazard in Southeastern Sicily, Annali di Geofisica, 44 (4), 723-738.

Barbano, M.S., R. Rigano, M. Cosentino and G. LomBARDO (2001): Seismic history and hazard in some localities of south-eastern Sicily, Boll. Geof. Teor. Appl., 4 (1-2), 107-120.

Barbano, M.S., R. AzZaro and D.E. Grasso (2005): Earthquake damage scenarios and seismic hazard of Messina, north-eastern Sicily (Italy) as inferred from historical data, J. Earth. Eng., 9 (6), 805-830.

Boschi, E., E. Guidoboni, G. Ferrari, G. Valensise and P.
Gasperini (1997): Catalogo dei Forti Terremoti in Italia dal 461 a.C. al 1990, (ING/SGA Bologna).

Boschi, E., E. Guidoboni, G. Ferrari, D. Mariotti, G. VALENSISE and P. GASPERINI (Eds.) (2000): Catalogue of Strong Italian Earthquakes from 461 B.C. to 1980, Annali di Geofisica, 43, 609-868.

BoschI, E. and E. GuIDOBONI (2003): I terremoti a Bologna e nel suo territorio dal XII al XX secolo, INGV-SGA, Bologna.

Camassi, R. (2002). La crisi sismica del 1997. I dati del rilievo macrosismico del terremoto Umbria-Marche 1997 in: Canti, M. and M.L. Polichetti (eds.), Il patrimonio culturale dall'emergenza sismica del 1997 al piano di ripristino recupero e restauro. il caso delle Marche, 31-38.

CAMASSI, R. and D. Molin (1994): I terremoti bolognesi del 1929, Bologna.

Camassi, R., E. Cova, E. Ercolani, G. Monachesi and L. PostPischl (1997a): Earthquakes of September and October 1997 in Umbria-Marche (Central Italy): Virtual exploration of the epicentral zone. Internet: http://emidius.mi.ingv.it/GNDT/UMEQ_VR/index_i.h tml

Camassi, R., H. Coppari, M. Frapiccini, G. Monachesi, S. Del Mese, L. Giovani, S. Maramai, A. Massucci, A. Tertulliani and D. Molin (1997b): Rilevamento macrosismico dell' area interessata da danni agli edifici in occasione di recenti terremoti. Interventi congiunti GNDT-ING-SSN per scopi di Protezione Civile (Assemb. Gen. GNDT, settembre, 1997, Roma).

Camassi, R., P. Galli, D. Molin, G. Monachesi and G. MoRelli (Editors), (1998). Rilievo macrosismico preliminare del terremoto umbro-marchigiano di settembre-ottobre 1997, Ingegneria Sismica, 14 (3), 22-26.

CECIC, I. and R.M.W. Musson (2004): Macroseismic Surveys in Theory and Practice, Nat. Haz., 31, 39-61.

Cubellis, E. and A. Marturano (2002): Mt. Vesuvius: a macroseismic study of the earthquake of october 9, 1999. J. Volcanol. Geotherm. Res., 118, 339-351.

D'Amico, S. and R. AzZARo (2008): MACROMAP: una utility per MapInfo ${ }^{\mathrm{TM}}$ per la georeferenziazione di dati macrosismici e la loro rappresentazione cartografica, Quaderni di Geofisica, 55, 21.

De Rubeis, V., P. Tosi, C. Gasparini and A. Solipaca (2005): Application of kriging technique to seismic intensity data, Bull. Seism. Soc. Am., 95 (2), 540-548.

FERrari, G. and E. GuIdoboni (2000): Seismic scenarios and assessment of intensity: some criteria for the use of the MCS scale, Annali di Geofisica, 43 (4), 707-720.

Gasparini, C., V. De Rubeis and A. Tertulliani (1992): A method for the analysis of macroseismic questionnaires, Nat. Haz., 5, 169-177.

Gasparini, C., M. Anzidei, S. Conte, S. Del Mese, V. De Rubeis, A. Maramai, A. Massucci, F. Riguzzi, A. Tertulliani, C. Vannucci and M. Vecchi (1997): Indagine macrosismica per la sequenza sismica Umbro-Marchigiana settembre-ottobre 1997, in Studi preliminari sulla sequenza sismica dell'Appennino Umbro-Marchigiano del settembre-ottobre 1997, edited by E. BosCHI and M. CocCO (Pubbl. ING, 593), 42-44.

Grünthal, G. (Editor) (1993): European Macroseismic Scale 1992 (up-dated MSK-scale). European Seismological Commission, subcommission on Engineering 
Seismology, working Group Macroseismic Scales. Conseil de l'Europe, Cahiers du Centre Européen de Géodynamique et de Séismologie, vol. 7, Luxembourg.

GrünthaL, G. (Editor) (1998): European Macroseismic Scale 1998 (EMS-98). European Seismological Commission, subcommission on Engineering Seismology, working Group Macroseismic Scales. Conseil de l'Europe, Cahiers du Centre Européen de Géodynamique et de Séismologie, vol. 15, Luxembourg.

Guidoboni, E. and G. FerRARI (2000): Historical variables of seismic effects: economic levels, demographic scales and buildings techniques, Annali di Geofisica, 43 (4), 687-705.

Mercalli, G. (1897): I terremoti della Liguria e del Piemonte, Memoria con tre tavole in litografia, Napoli.

Molin, D. (1995): Considerations on the assessment of macroseismic intensity, Annali di Geofisica, 38 (5/6), 805-810.

Molin, D. (2003): Considerazioni sull'eventuale adozione in Italia della scala macrosismica europea (EMS1998). $22^{\circ}$ Convegno Nazionale del GNGTS, Roma, 18-20 novembre 2003, Riassunti estesi delle comunicazioni, pp. 11.

Molin, D., P. Soddu, C. Gasparini, A. Tertulliani, R. CAMASSI, G. MonACHESI and M. STUCCHI (1997): Unificazione delle valutazioni degli effetti macrosismici dei terremoti umbro-marchigiani del settembre/ottobre 97. Rapporto Protezione Civile.

Monachesi, G., R. CAmassi and D. Molin (Editors) (1997): Earthquakes of September-October 1997 in Umbria-Marche (Central Italy): Macroseismic survey after the earthquakes of 26 September 1997 and following days. Internet: http://emidius.mi.ingv.it/GNDT/T19970926_eng/T19970926agg.html

Musson, R. M. W. and I. CECIC (2002): Macroseismology, in: LeE, W.H.K., H. Kanamori, P.C. Jennings, and C. KISSINGLER (Editors), International Handbook of Earthquake and Engineering Seismology, vol. 81A, $807-822$.
Postpischl, D., E. Chignola, G. Monachesi, S. RaccichiNi, A. Riggio, N. Vasapollo and L. VitTuari (1991): Progetto e sperimentazione di un nuovo questionario macrosismico, Gruppo Nazionale per la Difesa dai Terremoti, Atti del Convegno di Pisa. 25- 27 giugno, 261278.

QUEST (2008): Quick Earthquake Survey Team. Internet: http://www.ingv.it/real-time-monitoring/quest/questquick-earthquake-survey-team

SiEBERG, A. (1930): Geologie der Erdbeben, Handbuch der Geophysik, Berlin, 552-554.

SPONHEUER, W. and V. KARNIK (1964): Neue seismische Skala, in Sponheuer, W. (Editor), Proc. 7th Symp af the ESC, Jena, 24-30 Sept. 1962, 77, 69-76.

STUCCHI, M. (Editor) (1997): Earthquakes of SeptemberOctober 1997 in Umbria-Marche (Central Italy): Macroseismic data in terms of EMS-92 scale. Internet: http://emidius.mi.ingv.it/GNDT/T19970926_eng/EMS intro.html

Stucchi, M., R. CAmassi, A. Rovida, M. Locati, E. ERcolani, C. Meletti, P. Migliavacca, F. Bernardini and R. AzZARo, (2007): DBMI04, il database delle osservazioni macrosismiche dei terremoti italiani utilizzate per la compilazione del catalogo parametrico CPTI04. http://emidius.mi.ingv.it/DBMI04, Quaderni di Geofisica, 49, 38.

Tertulliani A. (1995): Testing the European Macroseismic Scale 1992 (EMS92) on Italian Earthquakes, European Earthquake Engineering, 2, 37-43.

TERTULLIANi A. (2000): Qualitative effects of local geology on damage pattern, Bull. Seism. Soc. Am., 90, 15431548.

Tosi, P., A. Tertulliani, V. De Rubeis and C. Gasparini (1999): Preliminary results of the macroseismic survey of the Colfiorito sequence (Central Italy), Phys. Chem. of the Earth., 24 (6), 477-482.

WAlD, D.J., V. Quitoriano, L.A. Dengler and J.W. DEWEY (1999): Utilization of the Internet for rapid community intensity maps, Seism. Res. Lett., 70 (6), 680-697. 